\title{
Characterization of the $\beta$-Adrenergic Receptor in Isolated Human Fetal Lung Type II Cells
}

\author{
CYNTHIA K. EWING, DIANE M. DUFFY, AND JAMES M. ROBERTS \\ Children's Hospital of San Francisco, Neonatology Department [C.K.E.]; Department of Obstetrics, Gynecology, \\ and Reproductive Sciences [C.K.E., J.M.R.]; Graduate Program in Endocrinology [D.M.D., J.M.R.]; and The \\ Cardiovascular Research Institute [J.M.R.], University of California, San Francisco, California 94143
}

\begin{abstract}
Functioning of the $\beta$-adrenergic response system is important for successful transition of the neonate from fetal life to breathing air. We characterized the $\beta$ adrenergic receptors on human fetal lung type II cells, the cell type responsible for many pulmonary responses sensitive to $\beta$-adrenergic stimulation. Type II cells were isolated from human fetal lung explants, and membrane particulates prepared from these cells were used for radioligand binding studies. ${ }^{125}$ I-iodocyanopindolol, a specific $\beta$ adrenergic antagonist, bound to a single class of saturable, high-affinity binding sites on type II cell membranes with a receptor concentration of $78 \pm 9 \mathrm{fmol}$ receptor $/ \mathrm{mg}$ membrane protein, a $k_{d}$ of $79 \pm 18 \mathrm{nM}$, and $958 \pm 120$ receptors per cell. Binding was stereoselective with $l$-propranolol binding with higher affinity than the inactive $d$-isomer. The binding site had the characteristics of a $\beta_{2}$-adrenergic receptor. The order of potency of $\beta$-adrenergic agonists was isoproterenol $>$ epinephrine $>>$ norepinephrine. The $\beta_{2}$-selective antagonist ICI 118551 competed for a single class of high-affinity sites. Agonist binding affinity was reduced in the presence of guanyl nucleotides, consistent with receptors coupled to guanine nucleotide binding proteins. $\beta$-Adrenergic agonists also stimulated adenylyl cyclase in these membrane preparations. ${ }^{125} \mathrm{I}$-iodocyanopindolol binding to membranes prepared from human fetal lung fibroblasts indicated fewer receptors $(404 \pm 68)$ than were present on type II cells. Work by others has suggested a difference in lung function and lung $\beta$-adrenergic receptor concentration between males and females. After culturing midgestation human fetal lung for $5 \mathrm{~d}$ we found no significant difference between the $\beta$-adrenergic receptor number per type II cell for male $(820 \pm 165)$ and female $(1107 \pm$ 220) specimens. (Pediatr Res 32: 350-355, 1992)
\end{abstract}

\section{Abbreviations}

ICYP, ${ }^{125}$ I-iodocyanopindolol

GPPNHP, guanosine $5^{\prime}$-imidodiphosphate

$\mathbf{K}_{\mathbf{i}}$, inhibition constant

Survival of a newborn requires several adaptive changes. Lungs that are fluid filled in utero must quickly and efficiently convert to a gas-exchange organ. Alveolar $\beta$-adrenergic responses contribute directly to this process. Stimulation of $\beta$-adrenergic receptors increases the net resorption of lung liquid (1) and both the

Received December 3, 1991; accepted May 4, 1992.

Correspondence and reprint requests: James M. Roberts, Magee Womens Hospital, Department of Ob/Gyn, 300 Halket St., Pittsburgh, PA 15213.

D.M.D. was supported by an ARCS foundation scholarship and NIH Training Grant HD-07263. synthesis and release of the components of pulmonary surfactant from the type II pneumocytes (1-3).

Neonates born without the benefit of labor have an increased incidence of respiratory difficulties (4). Circulating catecholamine levels rise during labor (5) and may improve lung function by the mechanisms described above. Consistent with this, treatment of fetal rabbits with an irreversible $\beta$-adrenergic antagonist (6) or prevention of epinephrine synthesis (7) results in a reduction in the release of surface active material that usually accompanies labor.

The observed advantage in lung function of females over males during the perinatal period (8) led to investigation of sex differences in lung function. Sex differences in circulating catecholamines, adrenal enzymes involved in catecholamine synthesis, and lung $\beta$-adrenergic receptor concentration (9) suggest that the $\beta$-adrenergic response system may contribute to the better pulmonary function seen in females.

Our previous studies demonstrated that $\beta$-adrenergic receptors were present and functional in human fetal lung during the 2 nd trimester of gestation (10). The present studies examine the properties of $\beta$-adrenergic receptors present on the type II pneumocyte, the cell type relevant to alveolar function. We report that, in membranes prepared from purified type II cells, $\beta$ adrenergic receptors of predominantly if not exclusively the $\beta_{2}$ subtype are present and functionally linked to adenylyl cyclase. Under the conditions of our experiments, we could not demonstrate a sex difference in the number of $\beta$-adrenergic receptors per human fetal lung type II cell.

\section{MATERIALS AND METHODS}

Materials. ${ }^{125} \mathrm{I}-( \pm)$ iodocyanopindolol (ICYP), sp act $81.4 \mathrm{TBq} /$ mmol was purchased from New England Nuclear Corporation (Boston, MA). Explants were maintained in Waymouth's media MB 752/1, supplemented with penicillin (100 U/mL), streptomycin $(100 \mathrm{mg} / \mathrm{mL})$, and fungizone $(2.5 \mathrm{mg} / \mathrm{mL})$ in the absence of serum. The UCSF Cell Culture Facility provided tissue culture media and supplies, including minimal essential medium, PBS, and STV $(0.05 \%$ trypsin, $0.02 \%$ EDTA, in saline with $1 \mathrm{~g} / \mathrm{L}$ glucose, $0.58 \mathrm{~g} / \mathrm{L} \mathrm{NaHCO}_{3}$ ). Calf serum was supplied by $\mathrm{Hy}$ Clone (Logan, UT). The Sigma Chemical Co. (St. Louis, MO) supplied other chemicals including forskolin and prostaglandin $\mathrm{E}_{1}$.

Tissue preparation and maintenance of explants. Human fetal lung tissue was obtained from 2 nd trimester elective terminations (16-20 wk gestation) under a protocol approved by the University of California, San Francisco Institutional Review Committee. The tissue was stored in sterile cell culture medium at $4^{\circ} \mathrm{C}$, and explants were prepared for culture within $18 \mathrm{~h}$ of receipt of the tissue.

Explant culture was performed as previously described (11) under sterile conditions. Lung tissue was dissected free of trachea, bronchi, obvious blood, and nerve tissue and chopped into 1- 
mm cubes using a McIlwain tissue chopper. The explants were plated on lightly scratched tissue culture dishes and maintained at $37^{\circ} \mathrm{C}$ in a humidified tissue incubator in an environment of $95 \%$ air and $5 \% \mathrm{CO}_{2}$. The explants were incubated for $5 \mathrm{~d}$ on a rocking platform that alternately exposed the explants to the incubator atmosphere and culture medium. The medium was changed daily.

Isolation of type II cells and fibroblasts. Type II cells were prepared by enzymatic digestion of lung explants and differential adhesion of the resulting cell suspension as previously described (12) with the following modifications. Centrifugation was for 8 min per spin, the primary adherence step was for $60 \mathrm{~min}$, and the secondary adherence step was for $20 \mathrm{~min}$. The population of nonadherent cells after the second adherence step was primarily type II cells (80\%) as assessed by light-microscopic identification of lamellar bodies and the cells were used immediately for membrane preparation. Adherent cells from the primary adherence step were primarily fibroblasts $(65 \%)$ as identified by the characteristic spindly shape when adherent. These cells were scraped from tissue culture dishes and used for membrane preparation. All cells were counted using a hemocytometer.

Membrane preparation. Immediately after isolation, the type II cells and fibroblasts were centrifuged at $400 \times g$ for $15 \mathrm{~min}$ at room temperature. The pellet was resuspended in a buffer of 50 mM Tris, 0.1 M EDTA, pH 7.4. Cells were then lysed by rapid freezing in liquid nitrogen and thawing at $26^{\circ} \mathrm{C}$. The lysate was then centrifuged at $29000 \times g$ and the supernatant discarded. The pellet was resuspended in $50 \mathrm{mM}$ Tris, $4 \mathrm{mM} \mathrm{MgCl}_{2}, \mathrm{pH}$ 7.4 (Tris- $\mathrm{Mg}$ ). The volume and protein concentration were determined. Membrane preparations were then quick-frozen in liquid nitrogen and stored at $-70^{\circ} \mathrm{C}$. Membrane protein recovery was $10 \pm 2 \mu \mathrm{g}$ per million cells for type II cells and $9 \pm 1 \mu \mathrm{g}$ per million cells for fibroblasts. Preliminary experiments indicated that binding of ICYP was stable for 8 wk but declined substantially after 6 mo of membrane storage. Experiments were performed within 4 wk of membrane preparation.

Binding assays. Receptor concentration was determined using the $\beta$-adrenergic antagonist ICYP. Fourteen $\mu \mathrm{g}$ of membrane particulate protein were incubated for $60 \mathrm{~min}$ at $30^{\circ} \mathrm{C}$ in a final volume of $0.25 \mathrm{~mL}$ of Tris- $\mathrm{Mg}$. After incubation, the samples were filtered through Whatman $\mathrm{GF} / \mathrm{C}$ glass fiber filters and washed four times with ice cold $5 \mathrm{~mL}$ Tris-Mg. The filters were then dried and counted in a Packard auto-gamma spectrometer.

In preliminary experiments, saturation analysis using concentrations of ICYP from 12.5 to $800 \mathrm{pM}$ and $100 \mu \mathrm{M}$ isoproterenol to define nonspecific binding indicated saturable ICYP binding with a dissociation constant of $64-73 \mathrm{pM}$, consistent with results in other tissues. To conserve tissue, in subsequent experiments a single concentration of ICYP $\left(100 \mathrm{pM}\right.$, about $\left.1.5 \mathrm{k}_{\mathrm{d}}\right)$, and 100 $\mu \mathrm{M}$ isoproterenol was used to define nonspecific binding. Receptor concentration was determined using the following relationship: receptor concentration $=\left(\mathrm{Lf}+\mathrm{k}_{\mathrm{d}}\right) \times \mathrm{PL} / \mathrm{Lf}$, where $\mathrm{Lf}$ is the concentration of free ligand, $\mathrm{k}_{\mathrm{d}}$ the dissociation constant of ICYP, and PL the specifically bound ICYP at that concentration. The results using this approach were not different from those performed by saturation analysis $[98 \pm 12(n=7)$ versus $81 \pm 6$ $(n=3) \mathrm{fmol} / \mathrm{mg}$ protein]. The number of receptors per cell was estimated by dividing the molar concentration of receptors per mg protein by the membrane protein per cell.

When agonists and antagonists were used to compete for ICYP binding, a concentration of $100 \mathrm{pM}$ ICYP was used.

$c A M P$ generation. Adenylyl cyclase activity was assessed using a modification of the assay described by Salomon et al. (13). Membrane particulate $(20-30 \mu \mathrm{g})$ was incubated for $10 \mathrm{~min}$ at $37^{\circ} \mathrm{C}$ in $50 \mathrm{mM} N$-2-hydroxyethylpiperazine- $N^{\prime}$-2-ethanesulfonic acid, $\mathrm{pH} 8.0$, containing $4 \mathrm{mM} \mathrm{MgCl}, 0.4 \mathrm{mM} \mathrm{ATP}, 18.5 \mathrm{kBq}$ ${ }^{32} \mathrm{P}-\alpha \mathrm{ATP}, 1 \mathrm{mM}$ cAMP, and a regenerating solution $(10 \mathrm{U} / \mathrm{mL}$ creatine phosphokinase and $10 \mathrm{mM}$ creatine phosphate) in a final volume of $50 \mu \mathrm{L}$. The reaction was stopped by addition of $1 \mathrm{~mL}$ of "stop solution" containing $10 \mathrm{mM}$ cAMP, 1 mM ATP, and $0.2 \%$ SDS. cAMP was separated from ATP using sequential Dowex alumina columns with ${ }^{3} \mathrm{H}$-cAMP added to monitor recovery, which was $80-95 \%$.

Determination of fetal sex. For many specimens, the fetal sex was determined by visual inspection of the gonads. When this determination was not available, the sex of isolated human fetal lung cells was determined using the polymerase chain reaction to amplify a specific Y-chromosome sequence. Cellular protein was digested with proteinase $\mathrm{K}(0.2 \mathrm{mg} / \mathrm{mL})$ in $10 \mathrm{mM}$ Tris, 100 $\mathrm{mM} \mathrm{NaCl}, 1 \mathrm{mM}$ EDTA, pH 8.0 with $0.5 \%$ SDS at $50^{\circ} \mathrm{C}$ overnight. After phenol:chloroform:isoamyl $(25: 24: 1)$ extraction and ethanol precipitation, the resulting DNA pellet was resuspended in a small volume of $10 \mathrm{mM}$ Tris, $1 \mathrm{mM}$ EDTA, pH 7.6. $\mathrm{Y}$ chromosome-specific oligonucleotide primers were used for sex determination. Primers for a sequence specific to the $\beta$ globin gene were used for control amplification. Both male and female DNA samples purified from lymphocytes were used as controls. Amplification reactions were carried out as described (14), except the samples were amplified for 25 cycles, each including a 30 -s denaturation step at $92^{\circ} \mathrm{C}$, a 25 -s annealing step at $50^{\circ} \mathrm{C}$, and a 30 -s elongation step at $72^{\circ} \mathrm{C}$. Resulting DNA was separated by PAGE.

Data analysis. Binding data was analyzed using an iterative nonlinear curve-fitting program (15). This curve-fitting analysis determines the parameters that best fit the mathematical model for that particular curve, as well as the model that best describes the data.

Saturation analysis from the binding assays was determined by examining bound as a function of free radioligand. The data is arrayed as described by Scatchard (16).

Radioligand binding in the competition experiments was evaluated as a function of concentration of competitor (15). Residual variance was compared with that of models of increasing complexity (greater than one class of binding sites). The model was accepted when models of increasing complexity did not result in a statistically significant reduction in the residual variance, as determined by $F$ test. This analysis determines the concentration of competitor reducing binding to particular sites by $50 \%\left(\mathrm{I}_{50}\right)$ and the percentage of total binding sites for which the competitor has this affinity. Because experiments were conducted at low concentrations of binding sites so that free radioligand was essentially constant, we used the relationship described by Cheng and Prusoff (17), $\mathrm{k}_{\mathrm{i}}=\mathrm{I}_{50} /(1+\mathrm{Lf})$, to determine the $\mathrm{k}_{\mathrm{i}}$ for competitors. In this equation, Lf is the concentration of free radioligand and $\mathrm{k}_{\mathrm{d}}$ its dissociation constant determined in independent experiments.

Statistical comparison of male and female type II cell $\beta$ adrenergic receptor concentrations was made using unpaired $t$ test. All data are presented as mean \pm SEM. Because each lung is cultured individually and preparations of type II cells are not combined except where specifically noted, the value of $n$ given represents the number of individual lungs tested.

\section{RESULTS}

ICYP bound saturably and with high affinity to a single class of binding sites in type II cell membranes (Fig. 1). Iterative nonlinear curve fitting of total binding was best described as binding to a high-affinity site $\left(\mathrm{k}_{\mathrm{d}}=75 \pm 11 \mathrm{pM}\right.$, maximum binding capacity $=80 \pm 6 \mathrm{fmol} / \mathrm{mg}$ protein, $n=3$ ) and a site that was not saturable at the concentrations of ICYP used in these experiments (12.5 to $800 \mathrm{pM})$. To verify that the highaffinity binding sites were $\beta$-adrenergic receptors, these results were compared with specific ICYP binding defined as that prevented by the $\beta$-adrenergic agonist isoproterenol $(0.1 \mathrm{mM})$. Similar analysis of "specific binding" indicated a single saturable site with a $\mathrm{k}_{\mathrm{d}}(79 \pm 18 \mathrm{pM})$ and receptor concentration $(78 \pm 9 \mathrm{fmol} /$ $\mathrm{mg}$ protein) similar to the high-affinity ICYP binding site determined in analysis of total bound ICYP. Kinetic determination of the rate constants confirmed the $\mathrm{k}_{\mathrm{d}}$ determined at equilibrium. 

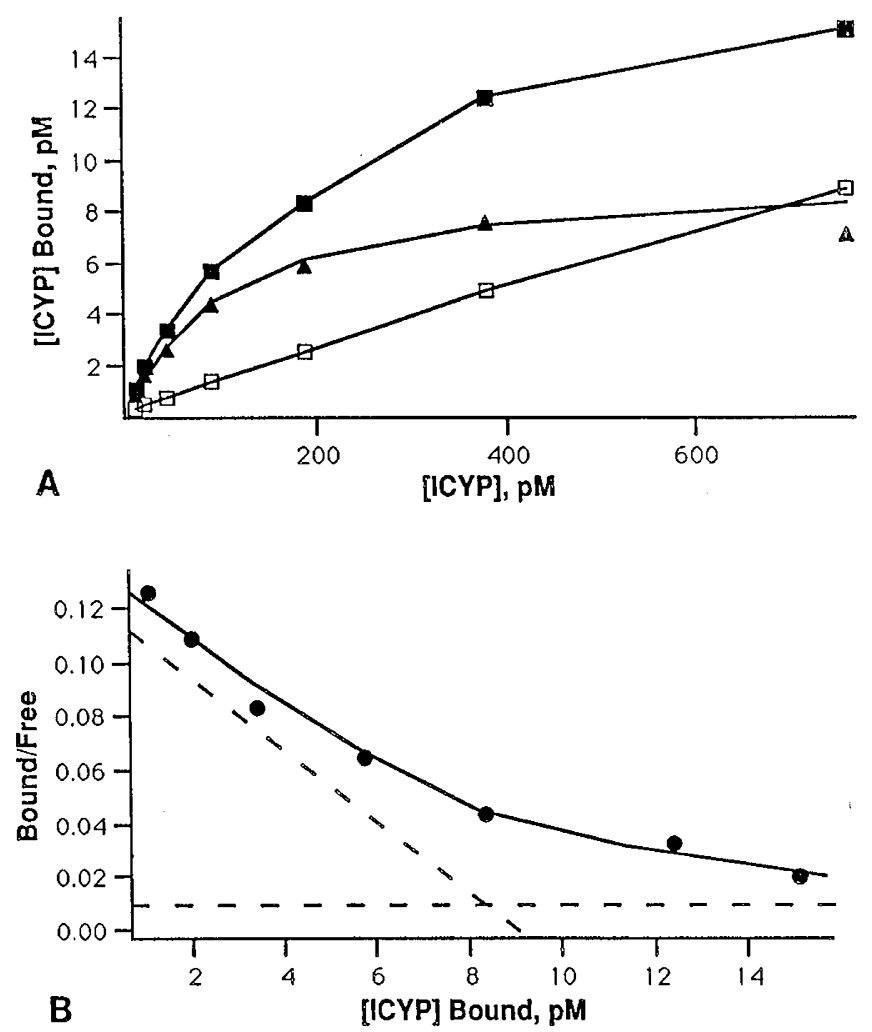

Fig. 1. Saturation analysis. Type II cell particulate $(0.06 \mathrm{mg} / \mathrm{mL}$ protein) was incubated for $60 \mathrm{~min}$ with ICYP at concentrations from 12.5 to $800 \mathrm{pM}$ with or without $0.1 \mathrm{mM}$ isoproterenol to define nonspecific binding as described in Materials and Methods. Data were analyzed by computer-assisted determination of either total bound ICYP or specific bound ICYP as a function of free ligand. Data are arrayed $(A)$ as a direct plot of total (E) and nonspecific binding $(\square)$ with calculated specific binding $(\boldsymbol{A})$ or a Scatchard array $(B)$ of total binding. In $B$, the actual data are indicated $(\bullet)$ as well as the computer-derived three-parameter fit (solid line) and the saturable and nonsaturable component curves (broken lines). The $\mathrm{k}_{\mathrm{d}}$ and maximum binding capacity determined by analysis of specific binding were $101 \pm 6 \% \mathrm{pM}$ and $94 \pm 5 \% \mathrm{fmol} / \mathrm{mg}$ protein and for total binding $73 \pm 19 \% \mathrm{pM}$ and $90 \pm 16 \% \mathrm{fmol} / \mathrm{mg}$ protein. Data presented are representative of two additional experiments.

In these experiments (Fig. 2), the forward rate constant, $\mathrm{k} 1$, was $2.3 \cdot 10^{8} \mathrm{M}^{-1} \cdot \mathrm{min}^{-1}$; the reverse rate constant, $\mathrm{k} 2$, was $2.7 \cdot 10^{-3}$; and the resulting $k_{d}(k 2 / k 1)$ was $12.4 \mathrm{pM}$, similar to the $k_{d}$ determined by equilibrium analysis.

Competition experiments confirmed that ICYP binding to membrane particulates had characteristics of a $\beta_{2}$-adrenergic receptor. The $\beta$-adrenergic antagonist propranolol competed stereoselectively for ICYP binding (Fig. 3). Competition by $l$-propranolol was complex. Analysis by iterative curve fitting indicated a proportion of high $\left(\mathrm{k}_{\mathrm{i}}=3 \mathrm{nM}, 42 \%\right)$ and low $\left(\mathrm{k}_{\mathrm{i}}=1.2\right.$ $\mu \mathrm{M})$ affinity sites, whereas the biologically inactive isomer, $d$ propranolol, competed with a single affinity similar to the lowaffinity binding of $l$-propranolol $\left(\mathrm{k}_{\mathrm{i}}=1 \mu \mathrm{M}\right)$. The proportion of ICYP binding for which $l$-propranolol competed with high affinity was similar to that prevented by $0.1 \mathrm{mM}$ isoproterenol. Thus, the nonstereoselective component of propranolol binding competes with ICYP binding to sites that are not the $\beta$-adrenergic receptor. When ICYP binding was examined in the presence of guanyl nucleotide to eliminate the contribution of efficacy to the interaction, the affinity of adrenergic agonists was isoproterenol $>$ epinephrine $>>$ norepinephrine (Fig. 4), suggesting that ICYP bound predominantly to $\beta_{2}$-adrenergic receptors in these preparations. The $\beta_{2}$ selective adrenergic antagonist ICI 118551 (Fig. 5 ) competed with a single high-affinity site $(1.1 \mathrm{nM})$, consistent with its affinity for $\beta_{2}$-adrenoreceptors (10).
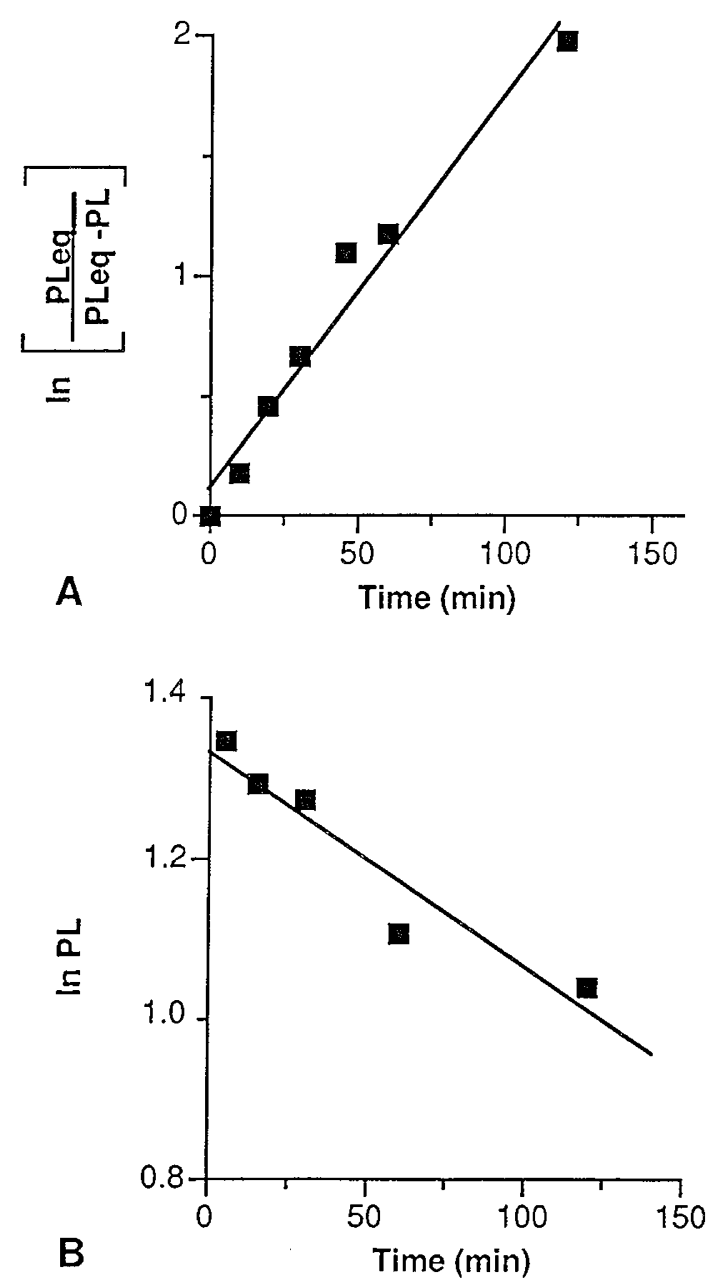

Fig. 2. Kinetic analysis. Type II cell particulate $(0.1 \mathrm{mg} / \mathrm{mL}$ protein $)$ was incubated with $60 \mathrm{pM} \mathrm{ICYP}$ with or without $0.1 \mathrm{mM}$ isoproterenol to define nonspecific binding. Samples were incubated at different times to a maximum of $180 \mathrm{~min}$. The data are arrayed $(A)$ as: $\ln [\mathrm{PLeq} / \mathrm{PLeq}$ - PL)], where PLeq is the concentration of ICYP bound at equilibrium and PL is the concentration of ICYP bound at times indicated, to determine the pseudo-1st-order rate constant, $\mathrm{k}_{\text {observed }}\left(0.016 \mathrm{~min}^{-1}\right)$. At $60 \mathrm{~min}$ of incubation, isoproterenol was added to parallel samples to achieve $0.1 \mathrm{mM}$ final concentration and reversal time was determined by measuring the concentration of ICYP [ICYP] bound at different times after addition of isoproterenol. Data are arrayed $(B)$ as the $\ln (\mathrm{PL}) v s$ time, to determine $\mathrm{k}_{\text {off }}\left(0.0027 \mathrm{~min}^{-1}\right)$. The forward rate constant $\mathrm{k}_{\text {on }}$ calculated from the relationship: $\mathrm{k}_{\text {on }}=\left(\mathrm{k}_{\text {observed }}-\mathrm{k}_{\mathrm{off}}\right) /[\mathrm{ICYP}]$ was 2.17 $\times 10^{8} \mathrm{~min}^{-1} \cdot \mathrm{M}^{-1}$. The $\mathrm{k}_{\mathrm{d}}\left(\mathrm{k}_{\text {off }} / \mathrm{k}_{\text {on }}\right)$ was $12.4 \mathrm{pM}$. Data presented are representative of one additional experiment.

$\beta$-Adrenergic receptors are linked through a guanine nucleotide binding protein to the stimulation of adenylyl cyclase. Because of this, agonist competition is influenced by guanyl nucleotides (18). When isoproterenol competition for ICYP was examined in the absence of added guanyl nucleotide (Fig. 6), the best fit indicated two classes of sites, $0.37 \mathrm{nM}(43 \%)$ and $76 \mathrm{nM}$. In the presence of $0.1 \mathrm{mM}$ guanosine $5^{\prime}$-imidodiphosphate, only the low-affinity, 120-nM, binding site was observed.

We compared $\beta$-adrenergic receptor concentration in cell populations enriched in either type II cells or fibroblasts. In these experiments, receptor concentration was determined using a single high concentration of radioligand (200 pM or approximately $3 \mathrm{k}_{\mathrm{d}}$ ) with specific binding defined by $0.1 \mathrm{mM}$ isoproterenol. In 10 fetal lungs, the type II cell $\beta$-adrenergic receptor concentration was $92.6 \pm 8.8 \mathrm{fmol} / \mathrm{mg}$ protein; in five fibroblast membrane preparations, determination of receptor concentration by this same method indicated $74.6 \pm 8.0 \mathrm{fmol} / \mathrm{mg}$ protein. 


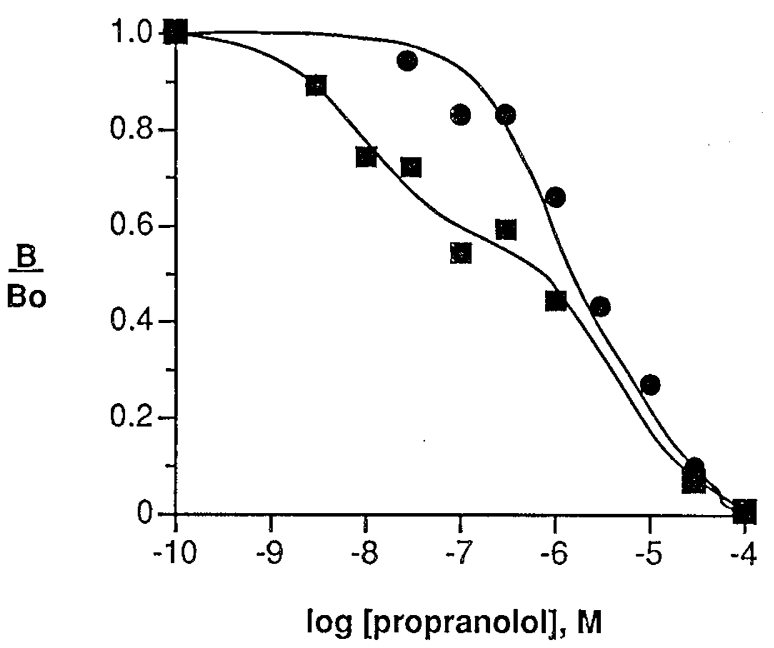

Fig. 3. Stereoselective competition by propranolol. Type II cell particulate $(0.1 \mathrm{mg} / \mathrm{mL}$ protein) was incubated with $100 \mathrm{pM}$ ICYP and the indicated concentrations of $l$ - or $d$-propranolol. Computer-assisted determination of effective concentration for half maximal response and subsequent determination of $\mathrm{K}_{\mathrm{i}}$ indicated that $l$-propranolol (耳) competed with $48 \%$ of the sites with an affinity of $3 \mathrm{nM}$ and with the remaining sites with an affinity of $1.5 \mu \mathrm{M}$. The $d$-propranolol $(\bullet)$ competed with a single affinity of $1.1 \mu \mathrm{M}$, similar to the low-affinity site bound by $l$ propranolol. Data presented are representative of one additional experiment.

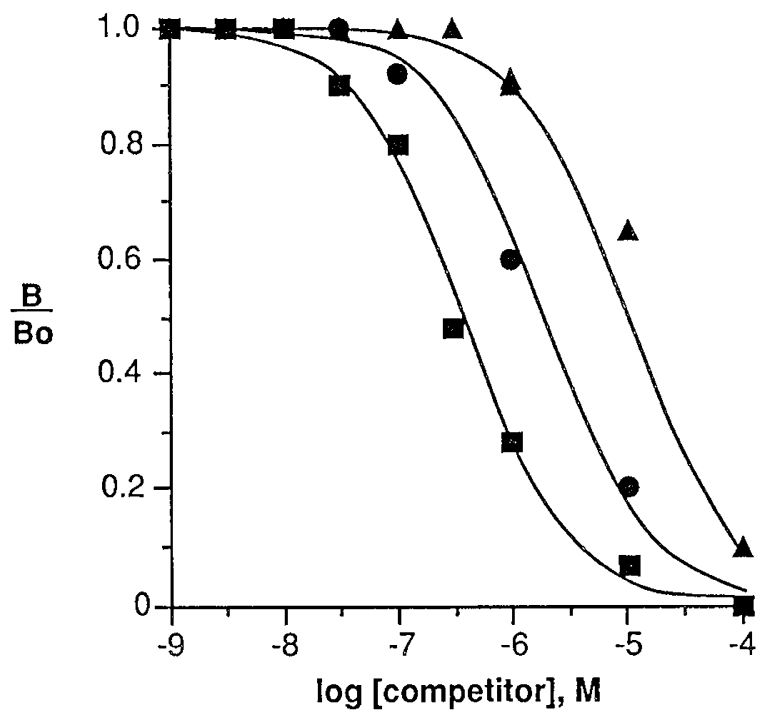

Fig. 4. Competition by adrenergic agonists. Type II cell particulate $(0.1 \mathrm{mg} / \mathrm{mL}$ protein) was incubated with $100 \mathrm{pM}$ ICYP in the presence of $0.1 \mathrm{mM}$ guanosine 5 -triphosphate. Data are expressed as binding at the indicated concentrations of isoproterenol $(\boldsymbol{\nabla})$, epinephrine $(\bullet)$, or norepinephrine (A) divided by ICYP binding in the absence of any competitor. Computer-assisted determination of effective concentration for half maximal response and subsequent determination of $k_{i}$ indicated that the affinity of isoproterenol $(0.12 \mu \mathrm{M})>$ epinephrine $(0.6 \mu \mathrm{M})>>$ norepinephrine $(3.4 \mu \mathrm{M})$. Data presented are representative of one additional experiment.

When these data were reexpressed to determine the number of $\beta$-adrenergic receptors per cell, we found $958 \pm 120 \beta$-adrenergic receptors per type II cell and $404 \pm 68 \beta$-adrenergic receptors per fibroblast.

The number of $\beta$-adrenergic receptors per type II cell was compared for membrane preparations from male and female fetuses. We found no significant difference in the number of $\beta$ adrenergic receptors per isolated type II cell between male $(820$

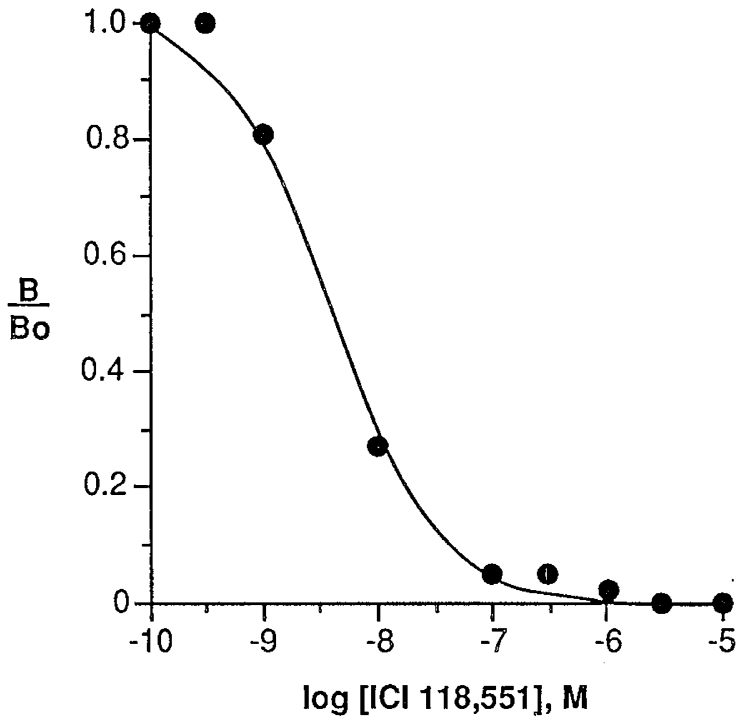

Fig. 5. Competition of the $\beta_{2}$-selective antagonist ICI 118551 . Type II cell particulate $(0.1 \mathrm{mg} / \mathrm{mL}$ protein $)$ was incubated with $100 \mathrm{pM}$ ICYP and the indicated concentrations of ICI 118 551. Data are expressed as binding in the presence of ICI 118551 divided by binding in the absence of competitor. Computer-assisted determination of effective concentration for half maximal response and subsequent determination of $\mathrm{k}_{\mathrm{i}}$ indicated that the $\beta_{2}$-antagonist competed with a single affinity $(1.1 \mathrm{nM})$. Experiment was performed on membranes pooled from three preparations.

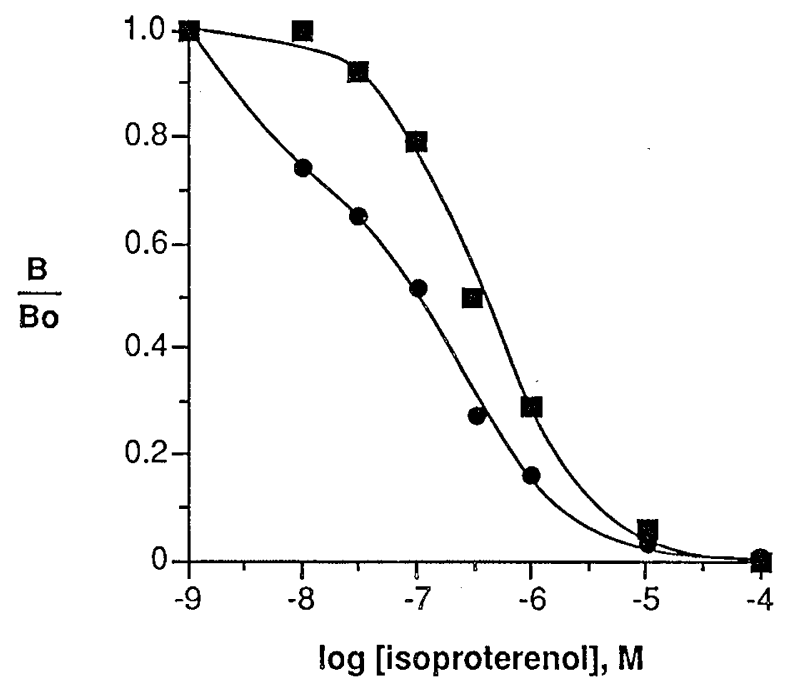

Fig. 6. Guanyl nucleotide sensitivity of agonist binding. Type II cell particulate $(0.1 \mathrm{mg} / \mathrm{mL}$ protein) was incubated with $100 \mathrm{pM}$ ICYP and the indicated concentrations of isoproterenol in the presence $(\mathbf{D})$ and absence $(\bullet)$ of $0.1 \mathrm{mM}$ guanosine $5^{\prime}$-imidodiphosphate. Data are expressed as binding in the presence of isoproterenol with or without guanosine $5^{\prime}$-imidodiphosphate divided by binding in the absence of isoproterenol and guanosine 5 '-imidodiphosphate. Computer-assisted determination of effective concentration for half maximal response and subsequent determination of $\mathrm{k}_{\mathrm{i}}$ indicated that, in the absence of guanyl nucleotide, isoproterenol competed for $43 \%$ of the sites with an affinity of $0.37 \mathrm{nM}$ and with the remaining sites with a 76-nM affinity, whereas with guanosine $5^{\prime}$-imidodiphosphate present competition was for a single class of sites with a $120-\mathrm{nM}$ affinity. Experiment was performed on membranes pooled from three preparations.

$\pm 165, n=6)$ and female $(1107 \pm 220, n=5)$ fetuses. There was also no difference between male $(90.0 \pm 12.9)$ and female $(101.1$ \pm 10.0 ) fetuses when data were compared when expressed as $\mathrm{fmol} \beta$-adrenergic receptor $/ \mathrm{mg}$ membrane protein. 
Adenylyl cyclase activation by $\beta$-adrenergic stimulation was evident in our membrane preparations (Fig. $7 A$ ). Isoproterenol increased stimulation by guanosine $5^{\prime}$-triphosphate alone 2.5 fold with an effective concentration for half maximal response of approximately $0.3 \mu \mathrm{M}$. Forskolin and guanosine $5^{\prime}-[\gamma$-thio $]$ triphosphate were both potent activators of adenylyl cyclase, but the effect of $1 \mu \mathrm{M}$ prostaglandin $\mathrm{E}_{1}$ was similar to the maximal effect of isoproterenol (Fig. 7B).

\section{DISCUSSION}

We studied $\beta$-adrenergic receptors using membrane particulate preparations because others have reported high nonspecific binding $(70 \%)$ of the lipophilic ligand ICYP when using isolated whole type II cells (19). Binding of ICYP at concentrations equal to the $\mathrm{k}_{\mathrm{d}}$ to membrane particulates resulted in only $25 \%$ nonspecific binding, which facilitated our characterization of the $\beta$ adrenergic receptors in these preparations. In preliminary studies, we confirmed the previously reported high nonspecific binding of ICYP to whole type II cells. Receptor number per isolated type II cell was similar to the results obtained in the experiments
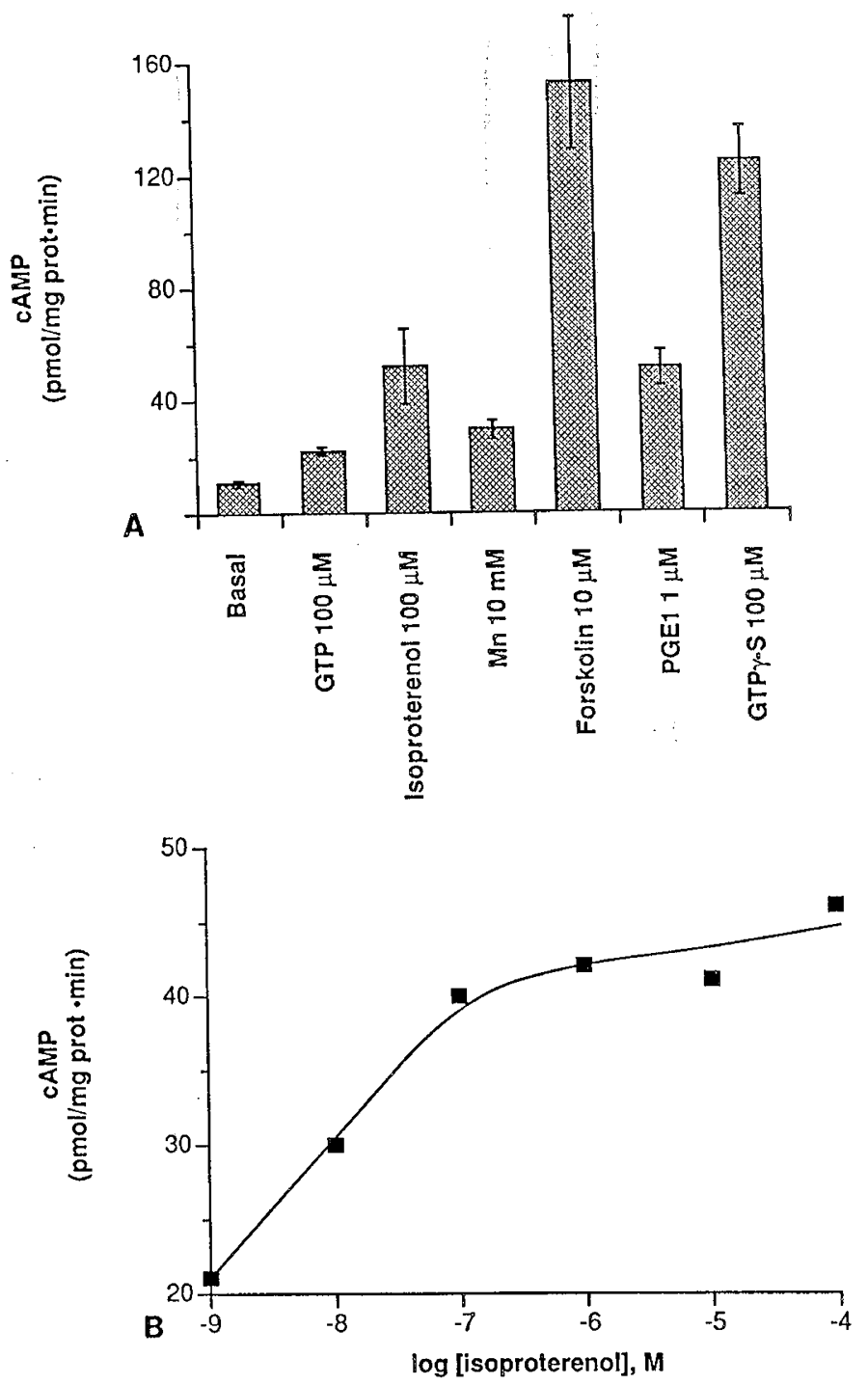

Fig. 7. Adenylyl cyclase activation in type II cell particulate. $A$, Type II cell particulate $(0.5 \mathrm{mg} / \mathrm{mL}$ protein) was incubated with the indicated concentration of several effectors $(n=3)$. GTP, guanosine $5^{\prime}$-triphosphate; $P G E 1$, prostaglandin $\mathrm{E}_{1} ; G T P \gamma-S$, guanosine $5^{\prime}$-[ $\gamma$-thio] triphosphate. $B$, Isoproterenol activates adenylyl cyclase in type II cell membrane particulate $(0.5 \mathrm{mg} / \mathrm{mL}$ protein). Data presented are representative of two additional experiments. described here using membrane particulates, suggesting that our method of enzymatic dispersal of type II cells does not dramatically reduce receptor concentration. Studies by others using rats $(19,20)$ and rabbits $(21)$ indicate lung $\beta$-adrenergic receptor concentrations of $6-43 \mathrm{fmol} / \mathrm{mg}$ membrane protein in these different preparations. Preliminary reported studies also have suggested that rat lung $\beta$-adrenergic receptors are of primarily the $\beta_{2}$ subtype (20). Our data indicate a higher receptor concentration and more receptors per type II cell than have been reported by others. This discrepancy may be because of species or age differences of the samples tested or because of differences in procedures, such as enzymatic dispersal of cells or method of membrane fraction preparation.

In the present study, we have demonstrated that $\beta$-adrenergic receptors are present and functional in membranes prepared from isolated human fetal lung cells. The binding site for the $\beta$ adrenergic antagonist ICYP was saturable, of high affinity, and stereoselective for the $\beta$-adrenergic antagonist propranolol. The $\mathrm{k}_{\mathrm{d}}$ of ICYP binding to type II cell membranes, as determined by equilibrium (79 pM) and kinetic (12.4 pM) analyses, although not identical, were in good agreement considering the errors inherent in these experiments. The specific $\beta_{2}$-adrenergic antagonist ICI 118551 identified only $\beta_{2}$-adrenergic receptors in membranes from type II cells. This is in contrast with data from fetal lung explant preparations in which $15-30 \%$ of the receptors were found to be of the $\beta_{1}$-adrenergic subtype $(10,22)$. The present data would indicate that cells other than the type II cell are the source of the $\beta_{1}$-adrenergic receptors in the lung.

Guanyl nucleotide-sensitive high-affinity binding indicates that the fetal $\beta$-adrenergic receptor, in this purified membrane preparation, is capable of interaction with the guanyl nucleotidesensitive coupling protein $\left(\mathrm{G}_{\mathrm{s}}\right)$ when occupied by agonist. This was confirmed by the activation of adenylyl cyclase by the $\beta$ adrenergic agonist isoproterenol.

Estimates of the concentration of $\beta$-adrenergic receptors indicated a greater concentration of these receptors in type II cells than in fibroblasts in membrane preparations from the isolated cells. Contamination by fibroblasts of the type II cell preparation is $20 \%$ and of the fibroblasts by type II cells $35 \%$, and calculations to correct for these contaminants suggest that fibroblasts contain few, if any, $\beta$-adrenergic receptors. This is consistent with our unpublished observation that the ability of isoproterenol to increase cAMP generation in intact cells is greater in type II cells than in fibroblasts.

We could not demonstrate a difference in $\beta$-adrenergic receptor number per cell on type II cells obtained from male and female fetuses. This contrasts with the findings of Padbury et al. (9) in the fetal rabbit lung, where they found a small but significant difference, with the greater concentration of $\beta$-adrenergic receptors found in lungs from female animals. Padbury's group examined $\beta$-adrenergic receptors in whole lung; we assayed membranes from isolated lung cells. Differences in species and gestational age also may play a role. Type II cells are not present in large numbers in human fetal lung during the period of gestation when it is available for study. Type II cells do differentiate during explant culture, making human fetal lung type II cells available for study. This differentiation takes place in culture, removed from the influence of factors such as serum estrogen and catecholamines, which regulate lung $\beta$-adrenergic receptors. Therefore, gender differences that may exist in vivo may be obscured by culture conditions necessary to obtain type II cells for these experiments. The limited sample number in our studies may also mask an actual difference in $\beta$-adrenergic receptor concentration between male and female fetuses. However, if differential maturation of $\beta$-adrenergic responses is involved in sex differences seen in the fetal lung, it seems unlikely that $\beta$-adrenergic receptor concentration is a major factor responsible for the female advantage in perinatal lung function. 


\section{REFERENCES}

1. Lawson EE, Brown ER, Torday JS, Mandansky DL, Taeusch Jr HW 1978 The effect of epinephrine on tracheal fluid flow and surfactant efflux in fetal sheep. Am Rev Respir Dis 118:1023-1026

2. Einhorning G, Chamberlain D, Conreras C, Burgoyne R, Robertson B 1977 Isoxsuprine-induced release of pulmonary surfactant in the rabbit fetus. Am J Obstet Gynecol 129:197-202

3. Dobbs LG, Mason RJ 1979 Pulmonary alveolar type II cells isolated from rats. Release of phosphatidylcholine in response to beta-adrenergic stimulation. J Clin Invest 63:378-387

4. Fredrick J, Butler NR 1972 Hyaline-membrane disease. Lancet 2:768-769

5. Nylund L, Lagercrantz H, Lunell N-O 1979 Catecholamines in fetal blood during birth in man. J Dev Physiol 1:427-430

6. McDonald Jr JV, Gonzales LW, Ballard PL, Pitha J, Roberts JM 1986 Lung beta-adrenergic receptor blockade affects perinatal surfactant release but not lung water. J Appl Physiol 60:1727-1733

7. Padbury JF, Jacobs HC, Lam RW, Conaway D, Jobe AH, Fisher DA 1984 Adrenal epinephrine and the regulation of pulmonary surfactant release in neonatal rats. Exp Lung Res 7:177-186

8. Fleisher B, Kulovich MV, Hallman M, Gluck L 1985 Lung profile: sex differences in normal pregnancy. Obstet Gynecol 66:327-330

9. Padbury JF, Hobel CJ, Lam RW, Fisher DA 1981 Sex differences in lung and adrenal neurosympathetic development in rabbits. Am J Obstet Gynecol 141:199-204

10. Davis DJ, Dattel BJ, Ballard PL, Roberts JM 1987 Beta-adrenergic receptors and cyclic adenosine monophosphate generation in human fetal lung. Pediatr Res 21:142-147

11. Gonzales LW, Ballard PL, Ertsey R, Williams MC 1986 Glucocorticoids and thyriod hormones stimulate biochemical and morphological differentiation of human fetal lung in organ culture. J Clin Endocrinol Metab 62:678-691

12. Ballard PL, Ertsey R, Gonzales LK, Liley HG, Williams MC 1986 Isolation and characterization of differentiated alveolar type II cells from fetal human lung. Biochim Biophys Acta 883:335-344

13. Salomon Y, Londos C, Rodbell M 1974 A highly sensitive adenylate cyclase assay. Anal Biochem 58:541-548

14. Pinckert TL, Lebo RV, Golbus MS 1989 Rapid determination of fetal sex by deoxyribonucleic acid amplification of $Y$ chromosome-specific sequences. Am J Obstet Gynecol 161:693-698

15. Roberts JM 1986 Techniques for the direct examination of adrenergic receptors in developmental studies. In: Nathanielsz PW (ed) Animal Models in Fetal Medicine, Vol 5. Perinatology Press, Ithaca, NY, pp 189-268

16. Scatchard G 1949 The attraction of proteins for small molecules and ions. Ann NY Acad Sci 51:660-672

17. Cheng Y, Prusoff WH 1973 Relationship between the inhibition constant $\left(k_{i}\right)$ and the concentration of inhibitor which causes 50 per cent inhibition $\left(\mathrm{I}_{50}\right)$ of an enzymatic reaction. Biochem Pharmacol 22:3099-3108

18. Gilman AG $1987 \mathrm{G}$ proteins: transducers of receptor-generated signals. Ann Rev Biochem 56:615-649

19. Fabisiak JP, Rannels SR, Vesell ES, Rannels DE 1986 Receptor-independent sequestration of beta-adrenergic ligands by alveolar type II cells. Am J Physiol 250:C871-C879

20. Fabisiak JP, Vesell ES, Rannels DE 1987 Interactions of beta-adrenergic antagonists with isolated rat alveolar type II pneumocytes. I. Analysis, characterization and regulation of specific beta-adrenergic receptors. J Pharmacol Exp Ther 241:722-727

21. Sommers Smith SK, Giannopoulos G 1983 Identification of beta-adrenergic receptors in pulmonary alveolar type II cells. Life Sci 33:2071-2078

22, Engel G 1981 Subclasses of beta-adrenoceptors: a quantitative estimation of beta 1 - and beta 2-adrenoceptors in guinea pig and human lung. Postgrad Med J 57(suppl 1):77-83 